\title{
Arginine Vasopressin Gene Regulation in the Homozygous Brattleboro Rat
}

Jin K. Kim, " Florent Soubrier," Jean-Baptiste Michel, ${ }^{\ddagger}$ Lise Bankir, ${ }^{5}$ Pierre Corvol, ${ }^{\ddagger}$ and Robert W. Schrier*

${ }^{*}$ Department of Medicine, University of Colorado School of Medicine, Denver, Colorado 80262; ${ }^{\ddagger}$ Institut National de la Santé et de la Recherche Medicale, U36, Laboratory of Experimental Medicine, College of France, 75005 Paris, France; and ${ }^{\S}$ Institut National de la Santé et de la Recherche Medicale U90, Department of Nephrology, Necker Hospital, 75015 Paris, France

\section{Abstract}

The Brattleboro rat, which has an autosomally recessive form of diabetes insipidus, has been reported to have a marked defect in the regulation of arginine vasopressin (AVP) gene expression. However, it is not known whether this is a primary genetic defect or occurs secondary to the urinary water losses which occur in the absence of circulating AVP in the Brattleboro rat. This present study was therefore undertaken to study AVP gene regulation in the Brattleboro rat after chronic AVP treatment by osmotic minipump for 2 wk. In Brattleboro rats without AVP treatment, neither urinary osmolality (Uosm) nor hypothalamic AVP mRNA was significantly changed after 24 $h$ of fluid deprivation (Uosm, $413 \pm 33$ to $588 \pm 44$, NS; AVP mRNA, 39.33 \pm 2.95 to $46.39 \pm 2.71 \mathrm{pg} / \mu \mathrm{g}$ total RNA, NS). In contrast, when Brattleboro rats were treated with AVP for 2 wk, the regulation of AVP gene occurred in response to $24 \mathrm{~h}$ of fluid deprivation. In these studies, hypothalamic AVP mRNA was significantly increased compared with the Brattleboro rats still receiving AVP with free access of water (28.9 $\pm 3.5 \mathrm{vs}$. $65.0 \pm 3.3 \mathrm{pg} / \mu \mathrm{g}$ total RNA, $P<0.001)$. Further studies in Long-Evans rats demonstrate a similar response to a comparable degree of fluid deprivation as Uosm and AVP mRNA were significantly increased after $72 \mathrm{~h}$ of fluid deprivation (Uosm, $1,505 \pm 186$ to $5,460 \pm 560 \mathrm{mosmol} / \mathrm{kg}, P<0.001 ; A V P$ mRNA, 31.7 \pm 3.9 to $77.5 \pm 4.6 \mathrm{pg} / \mu \mathrm{g}$ total RNA, $P<0.001$ ). These results indicate that AVP-replaced homozygous Brattleboro rats can regulate AVP gene expression normally in response to fluid deprivation. This finding indicates that the defect in AVP gene regulation in the Brattleboro rat not receiving AVP replacement is a secondary phenomenon rather than a primary genetic defect. (J. Clin. Invest. 1990. 86:14-

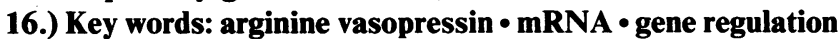
- Brattleboro rat

\section{Introduction}

The homozygous Brattleboro rat, a species of Long-Evans rat, has been shown to have an autosomally recessive form of central diabetes insipidus. The Brattleboro rat has neurons that lack the ability to synthesize arginine vasopressin (AVP) or its neurophysin (1). Recent studies examining the gene for the AVP prehormone from the Brattleboro rat showed a deletion

Address correspondence and reprint requests to Jin $\mathrm{K}$. Kim, Ph.D., University of Colorado, School of Medicine, 4200 E. 9th Avenue, Denver, CO 80262.

Received for publication 4 November 1988 and in revised form 12 February 1990

J. Clin. Invest.

(c) The American Society for Clinical Investigation, Inc.

$0021-9738 / 90 / 07 / 0014 / 03 \$ 2.00$

Volume 86, July 1990, 14-16 of a single guanosine residue in exon $B$ which encodes the conserved part of neurophysin (2-4). This mutant gene is correctly transcribed and spliced, but the resulting mRNA is not efficiently translated. The reason for the deficiency of circulating AVP is not clear, but it has been suggested that its mRNA is translated into a mutated precursor $(4,5)$. It has also been suggested that the AVP precursor in the Brattleboro rat with its mutated $\mathrm{COOH}$ terminus may exhibit features that are inappropriate for correct translocation of a secretory protein across the endoplasmic reticulum membrane (5).

In addition to the guanosine residual deletion, the Brattleboro rat has also been reported to have a marked defect in the regulation of AVP gene expression (6). In an earlier study, the Brattleboro rat was unable to increase hypothalamic AVP mRNA content in response to water deprivation. Thus, the Brattleboro rat may have two genetic defects accounting for the central diabetes insipidus. The defect of AVP gene regulation could, however, be a phenomenon that occurs secondary to the absence of circulating AVP and the accompanying water diuresis. The present study was therefore undertaken to determine whether normal regulation of AVP gene expression can be restored in the Brattleboro rat by 2 wk of treatment with exogenous AVP studies. The Long-Evans rat, which exhibits normal urinary concentrating capacity, served as the control for AVP gene regulation in response to fluid deprivation.

\section{Methods}

In one set of studies, male Brattleboro rats $(150 \mathrm{~g} \mathrm{b.w.)}$ were divided into groups 1 and 2 . Both groups 1 and 2 received AVP $(840 \mathrm{ng} / \mathrm{d})$ by Alzet osmotic minipump (Alza Corp., Palo Alto, CA) for 2 wk with ad lib. water. After 2 wk of AVP administration, the osmotic minipump was removed from group 2 and the rats were deprived of water for $24 \mathrm{~h}$. In another set of studies, 20 Long-Evans rats and 18 Brattleboro rats were divided into two groups. Half of the Brattleboro rats were water deprived for $24 \mathrm{~h}$ and half of the Long-Evans rats were water deprived for $72 \mathrm{~h}$. This duration of fluid deprivation has been shown to produce a comparable degree of dehydration, as assessed by decreased body weights and rise in plasma osmolality (Posm), ${ }^{1}$ in these homozygous Brattleboro and Long-Evans species. Urine was collected for $24 \mathrm{~h}$ before, during, and at the end of the experimental period as body weights were also measured. At the end of AVP treatment and urine sample collection, the rats were killed by decapitation, the hypothalamus was rapidly dissected under stereomicroscope, quickly frozen in the liquid nitrogen, and stored at $-80^{\circ} \mathrm{C}$ until extraction of total RNA.

Extraction of total RNA. Total RNA of the rat hypothalamus was extracted by a modified method of Chirgwin et al. (7) and Rehbein et al. (8). Briefly, the hypothalamus $(50-70 \mathrm{mg}$ ) was homogenized in $1 \mathrm{ml}$ of freshly prepared homogenizing solution ( $4 \mathrm{M}$ guanidinium thiocyanate, $5 \mathrm{mM} \mathrm{Na}$ citrate, $7 \% \beta$-mercaptoethanol) using a Polytron (Brinkmann Instruments Co., Westbury, NY) with low speed. After

1. Abbreviations used in this paper: Posm, plasma osmolality; Uosm, urinary osmolality. 
homogenization, $\mathrm{CsCl}(0.4 \mathrm{~g} / \mathrm{ml})$ was added to the homogenates and the homogenates were carefully layered on the top of $1 \mathrm{ml}$ cushion solution (5.7 M CsCl, $50 \mathrm{mM}$ EDTA, pH 7.5). The rest of the space in the tubes was filled up with paraffin oil. The sample was centrifuged for $20 \mathrm{~h},\left(20^{\circ} \mathrm{C}\right.$ at $\left.30,000 \mathrm{rpm}\right)$. After centrifugation, the supernatant was quickly removed by aspiration. The clear pellet was washed twice with $70 \% \mathrm{EtOH}$ and dissolved in $350 \mu \mathrm{l}$ of $100 \mathrm{mM}$ sodium acetate buffer with $20 \mathrm{mM}$ EDTA, pH 6.0. $2.5 \mathrm{vol}$ of $100 \% \mathrm{EtOH}$ was then added to the solution, which was stored at $-20^{\circ} \mathrm{C}$ for overnight. The precipitated total RNA was recovered by centrifugation $(20,000 \mathrm{rpm}$ for 30 min at $-5^{\circ} \mathrm{C}$ ), washed with $70 \% \mathrm{EtOH}$, and dissolved in sterile distilled water. The quantity of the extracted total hypothalamic RNA was determined by spectrophotometry $\left(\mathrm{OD}_{260}\right)$ and the quality of RNA was routinely checked by $1 \%$ agarose gel electrophoresis. The total hypothalamic RNA from one rat was 50-70 $\mu \mathrm{g}$.

Determination of AVP $m R N A$. A rat cDNA specific for the AVP gene precursor (provided by Drs. Schmale and Richter, University of Hamburg, Hamburg, W. Germany) was used for preparation of both antisense and sense strand AVP RNA. The specificity was tested by Northern blot. Hypothalamic AVP mRNA was determined by solution hybridization (9). Briefly hybridization was carried out in a reaction mixture containing $600 \mathrm{mM} \mathrm{NaCl}, 4 \mathrm{mM}$ EDTA, $10 \mathrm{mM}$ Tris, $\mathrm{pH}$ 7.5, 46\% formamide, ${ }^{35} \mathrm{~S}$-asRNA (AVP-antisense strand RNA) as a probe $(3,000 \mathrm{cpm} /$ tube), and $5 \mu \mathrm{g}$ sample (total extracted RNA) in a final volume of $30 \mu \mathrm{l}$ in an Eppendorf tube. The reaction solution was covered with $100 \mu \mathrm{l}$ paraffin oil to prevent evaporation and incubated at $68^{\circ} \mathrm{C}$ for $20 \mathrm{~h}$. Each hybridization included a standard curve consisting of $62.5,125,250$, and 500 pg AVP sRNA (AVP-sense strand RNA). Each hybridization of a standard or sample was performed in duplicate.

After hybridization, $1 \mathrm{ml}$ of $\mathrm{S} 1$ nuclease buffer $(8 \mathrm{U} / \mathrm{ml} \mathrm{S1} \mathrm{nu-}$ clease, $100 \mu \mathrm{g} / \mathrm{ml}$ herring-sperm DNA, $300 \mathrm{mM} \mathrm{NaCl}, 30 \mathrm{mM}$ $\mathrm{NaAcO}$, and $3 \mathrm{mM} \mathrm{ZnAcO}, \mathrm{pH} 4.2$ ) was added to remove any unhybridized probe. Then the reaction mixture was incubated at $60^{\circ} \mathrm{C}$ for 1 $\mathrm{h}$ and terminated by addition of $100 \mu \mathrm{l}$ of $6 \mathrm{M}$ TCA. After vortexing, the precipitated samples were separated by filtration using $2.4 \mathrm{~cm}$ GF/C filters (Whatman Inc., Clifton, NJ). The filters were washed three times with $3 \%$ TCA and finally with $95 \%$ ethanol, and counted in a 2-ml scintillation cocktail (Insta gel; Packard Instrument Co. Inc., Downers Grove, IL).

Both ${ }^{35}$ S-labeled asRNA (probe) and AVP sRNA (standard) were produced by in vitro transcription using rat AVP CDNA and Riboprobe System Transcription (Promega Biotec, Madison, WI). The in vitro transcribed probes were checked by agarose gel with a molecular weight marker. AVP cDNA has $230 \mathrm{bp}$. In the standard curve, hybridization was linear up to $500 \mathrm{pg}$ of AVP sRNA. The in vitro transcribed cRNA probe corresponds to the sequence complementary to a Pst I-Dra I fragment of rat AVP cDNA and corresponding to the AVP specific part of the mRNA (10). The specificity of the AVP mRNA probe was checked by Northern blot hybridization. The data were analyzed by one-way analysis of variance and the Newman-Keuls analysis.

\section{Results and Discussion}

The studies in the untreated homozygous Brattleboro and Long-Evans rats revealed comparable decreases in body weights (13.2 vs. $16.4 \%$, NS) and a rise in Posm (5.4 vs. $3.0 \%$, NS) with the respective 24 and $72 \mathrm{~h}$ of fluid deprivation. The urinary osmolality (Uosm) increased from $1,505 \pm 186$ to $5,460 \pm 560 \mathrm{mosmol} / \mathrm{kg} \mathrm{H}_{2} \mathrm{O}$ in the Long-Evans rats but there was no increase in Uosm $(413 \pm 33$ to $588 \pm 44 \mathrm{mosmol} / \mathrm{kg}$ $\mathrm{H}_{2} \mathrm{O}$, NS) in the Brattleboro rats. As shown in Fig. 1, the fluid deprivation was associated with an increase in mRNA in the Long-Evans but not Brattleboro rats.

These results shown in Fig. 1 thus confirm earlier results

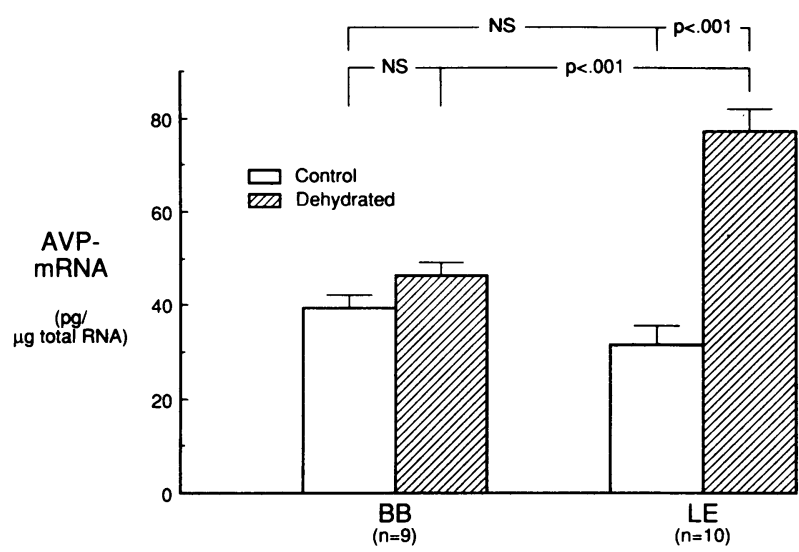

Figure 1. Hypothalamic AVP mRNA in the Long-Evans (LE) rat and Brattleboro (BB) rat before and after water deprivation. Each bar represents mean \pm SEM.

that the untreated Brattleboro rat does not exhibit AVP mRNA regulation in response to fluid deprivation (6). In Fig. 2 are shown the AVP mRNA of Brattleboro rats treated with AVP for 2 wk. In one group, the AVP administration by osmotic minipump was discontinued for $24 \mathrm{~h}$. These Brattleboro rats exhibited regulation of AVP mRNA as compared with the Brattleboro rats, who continued to receive AVP. Moreover, the degree of AVP mRNA regulation in response to $24 \mathrm{~h}$ of AVP removal in the Brattleboro rat was comparable to that observed in the Long-Evans rat (Figs. 1 and 2).

The present study therefore confirms the results of Majzoub et al. (6) that the untreated Brattleboro rat exhibits a defect in mRNA gene regulation in response to fluid deprivation. This defect in gene regulation is in addition to the guanosine residue deletion in Brattleboro rats which has been identified by Schmale and Richter (2). These findings thus suggest that two primary genetic defects may be involved in

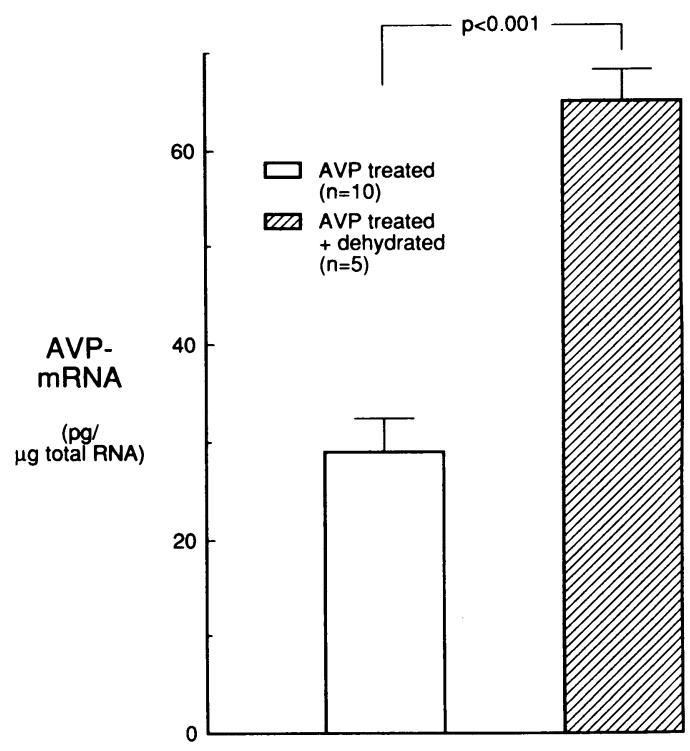

Figure 2. AVP mRNA in the hypothalamus of Brattleboro rats treated with AVP for 2 wk (open bar) and Brattleboro rats also treated for 2 wk with AVP but then examined $24 \mathrm{~h}$ after AVP removal (hatched bar). Each bar represents mean \pm SEM. 
the central diabetes insipidus state observed in the Brattleboro rats. An alternative hypothesis, however, is that the defect in gene regulation in Brattleboro rats is a phenomenon which occurs secondary to the absence of AVP.

To examine this possibility, Brattleboro rats were treated with exogenous AVP for two wk, after which the response of AVP mRNA to fluid deprivation was studied. In contrast to the untreated Brattleboro rats, those treated with AVP exhibited a significant rise in AVP mRNA with fluid deprivation. Moreover, the AVP mRNA regulation that occurred in response to fluid deprivation in AVP-treated Brattleboro rats appeared normal. Specifically, the rise in mRNA for the same degree of dehydration, as' assessed by percentage of body weight loss and rise in Posm with fluid deprivation, was comparable for the AVP-treated homozygous Brattleboro rats and the Long-Evans rats. The abnormal AVP gene regulation that occurs in response to chronic AVP absence may involve depletion of hypothalamic preprohormone, but further studies will be necessary to examine the specific mechanism.

The present study therefore demonstrates that the defect in AVP gene regulation in Brattleboro rats with fluid deprivation occurs secondary to the absence of circulating AVP and is reversible after 2 wk of AVP replacement. The results therefore support the interpretation that the guanosine residue deletion is the primary genetic defect causing diabetes insipidus in the Brattleboro rat and that the defect in AVP gene regulation is a secondary phenomenon. Further studies involving gene replacement will be necessary to test this hypothesis definitively.

\section{Acknowledgments}

The authors wish to thank Drs. Hartwig Schmale and Dietmar Richter for their gift of rat AVP cDNA, and Linda Benson for secretarial assistance.

This work was supported in part by the National Institutes of
Health, and Institute National de la Santé et de la Recherche Medicale, France.

\section{References}

1. Valtin, H., and H. A. Schroeder. 1964. Familial hypothalamic diabetes insipidus in rats (Brattleboro strain). Am. J. Physiol. 206:425-430.

2. Schmale, H., and D. Richter. 1984. Single base deletion in the vasopressin gene is the cause of diabetes insipidus in Brattleboro rats. Nature (Lond.). 308:705-709.

3. Schmale, H., R. Ivell, M. Briendl, D. Darner, and D. Richter. 1984. The mutant vasopressin gene from diabetes insipidus (Brattleboro) rats is transcribed but the message is not efficiently translated. EMBO (Eur. Mol. Biol. Organ.) J. 3:3289-3293.

4. Ivell, R., H. Schmale, B. Krisch, P. Nahke, and D. Richter. 1986. Expression of a mutant vasopressin gene: differential polyadenylation and read-through of the mRNA $3^{\prime}$ end in a frame-shift mutant. $E M B O$ (Eur. Mol. Biol. Organ.) J. 5:971-977.

5. Richter, D. 1988. Molecular events in expression of vasopressin and oxytocin and their cognate receptors. Am. J. Physiol. 255:F207F219.

6. Majzoub, J. A., E. J. Carrozana, J. S. Schulman, K. M. Baker, and R. L. Emanuel. 1987. Defective regulation of vasopressin gene expression in Brattleboro rats. Am. J. Physiol. 252:E637-E642.

7. Chirgwin, J. M., A. E. Przybyla, R. J. McDonald, and W. J. Rutter. 1979. Isolation of biologically active ribonucleic acid from sources enriched in ribonuclease. Biochemistry. 18:5294-5299.

8. Rehbein, M., M. Hillers, E. Mohr, R. Ivell, S. Morley, H. Schmale, and D. Richter. 1986. The neurohypophyseal hormones vasopressin and oxytocin, precursor structure, synthesis and regulation. Biol. Chem. Hoppe-Seyler. 367:695-704.

9. Durnam, D. M., and R. D. Palmita. 1983. A practical approach for quantitating specific mRNAs by solution hybridization. Anal. Biochem. 131:385-393.

10. Schmale, H., S. Heinsohn, and D. Richter. 1983. Structural organization of the rat gene for the arginine vasopressin-neurophysin precursor. EMBO (Eur. Mol. Biol. Organ.) J. 2:763-767. 